Ines Unetič, Metoda Kemperl

\title{
Vrt ob škofijski palači v Ljubljani
}

Ključne besede: vrtna umetnost, škofijska palača, Ljubljana, urbanizem, Ilirske province, bidermajer

V Zbirki načrtov Arhiva Republike Slovenije pod signaturo AS 1068, 6/50 najdemo načrt, ki prikazuje dve vrtni zasnovi. Opremljen je $\mathrm{z}$ legendo, merilom in pripisom Alluminatenbau, zato so že popisovalci zbirke domnevali, da je nastal za lokacijo v neposredni bližini semenišča. V popisu zbirke ima načrt naslov Nadškofijska palača: vrt.

S pregledom drugih arhivskih virov, načrtov Ljubljane iz 18. in predvsem 19. stoletja, s pregledom literature ter stilno analizo drugih vrtnih zasnov sva poskušali ugotoviti, za kateri prostor je nastal načrt, določiti čas nastanka načrta in vrta, najti naročnika, določiti slog načrtovanih vrtnih zasnov ter poiskati domnevnega avtorja načrta.

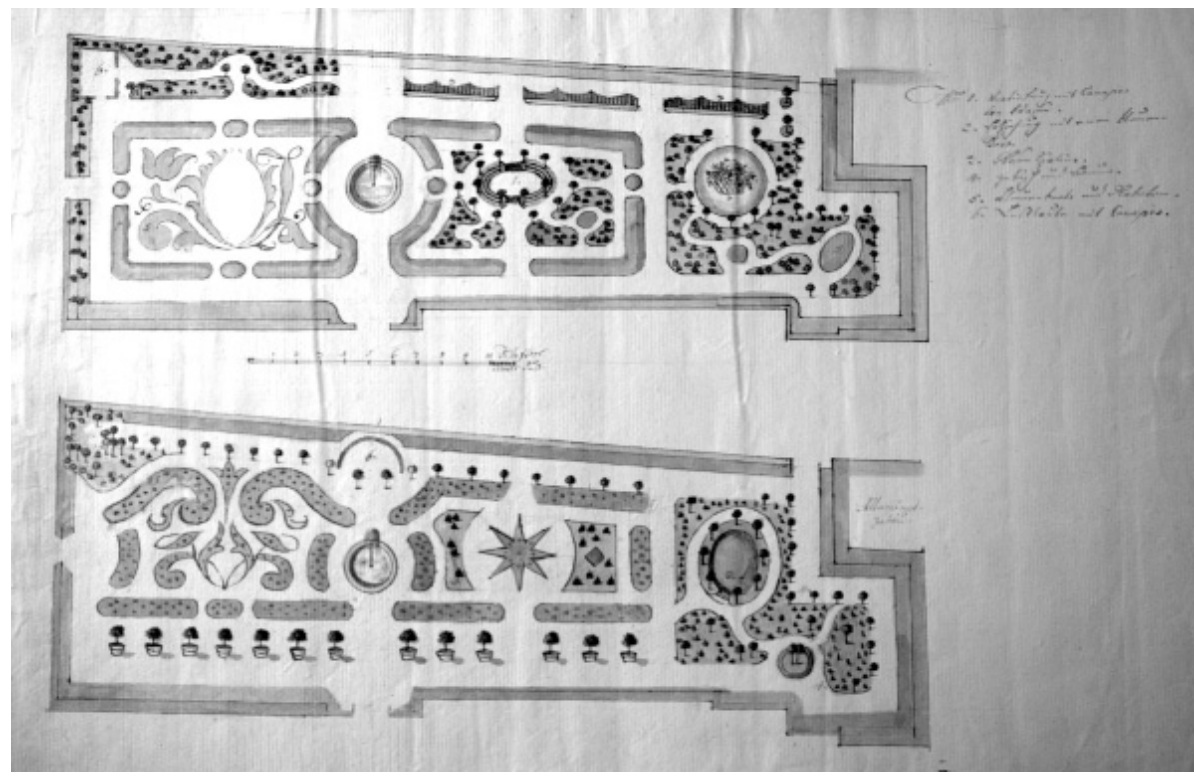

Slika 1: Načrt vrtnih zasnov

vir: Arhiv Republike Slovenije 
Kot je mogoče razbrati iz oblike in velikosti parcele načrtovanega vrta, nam načrt prikazuje dva različna predloga ureditve istega prostora. Zasnovi sta si v marsičem podobni. V obeh primerih je vrt ograjen (najverjetneje z zidcem) ${ }^{1}$ in razdeljen na dva po velikosti nesorazmerna dela, pri čemer večjega v sredini krasi vodomet. Natančnejši pogled razkrije, da sta fontani pri obeh predlogih enako in zelo preprosto oblikovani, le da je na prvi zasnovi (oziroma zgornji na listu) fontana na sečišču linij, ki vodita skozi južni in zahodni vhod, na drugi zasnovi (oziroma spodnji na listu) pa le v liniji, ki vodi skozi južni vhod. Pri prvi zasnovi je osrednji del razdeljen na tri segmente, obrobljene $\mathrm{z}$ borduro oziroma zasajenimi pasovi; največjega krasi vezeninast vzorec. $\mathrm{V}$ manjšem delu je nepravilno razdrobljena zelena površina s poglobitvijo (boulgreen), ${ }^{2}$ poudarjeno s striženimi drevesci, med njima pa stoji vodomet. Ob zahodnem in severnem robu prve zasnove so posamezni pasovi - eden je oblikovan enostavno, drugega predstavlja vijugasta pot $\mathrm{z}$ okrasnim drevjem in kanapeji, tretjega pa sestavljajo cvetlični špalirji. Manjši del na zahodu je organsko členjena zelena površina s povišanim okroglim delom, ki ga krasi cvetlična gredica oziroma blumen Korb. Spodnja zasnova ima podobne sestavne dele, le da so nekoliko drugače porazdeljeni. Poglobitev je v tem primeru na vzhodnem delu, prav tako znotraj organsko oblikovane površine. Severni rob gradi linija striženih drevesc s kanapejem in $\mathrm{z}$ neenakomerno zasajeno površino v vogalu. Tudi južni rob gradijo strižena drevesca, ki so v nasprotju z zgornjimi zasajena v posodah. Središčna površina je sestavljena iz razdrobljenih pasov raznih oblik in vezeninastega vzorca. Podobnost med zasnovama nakazuje tudi legenda, saj se nekatere od šestih postavk pojavijo v obeh primerih (elementi, zapisani pod točko 2 in 6).

Na zgornjem desnem robu načrta je legenda, ki razlaga določene dele vrta, in sicer:

1. Vertifung mit Canapes von Vasen (poglobitev s kanapeji in vazami)

2. Erhohung mit einem blumen Korb (dvignjena površina s cvetlično košaro)

3. Rosen Spalier (špalir iz vrtnic)

4. Gebusch und Baume (grmovnice in drevje)

5. Blumenbeete und Rabaten (cvetlične grede in pasovi)

6. Lustlaube mit Canapes (paviljoni oziroma senčne ute za razvedrilo s kanapeji).

1 Zidana ograja bi takšen bogato okrašen vrt varovala pred vsiljivci, tudi ognjem.

2 Boulgreen oziroma poglobljeni deli vrta, namenjeni športni in dramski igri ali samo razvedrilu (Kluckert, 2000, 230). 


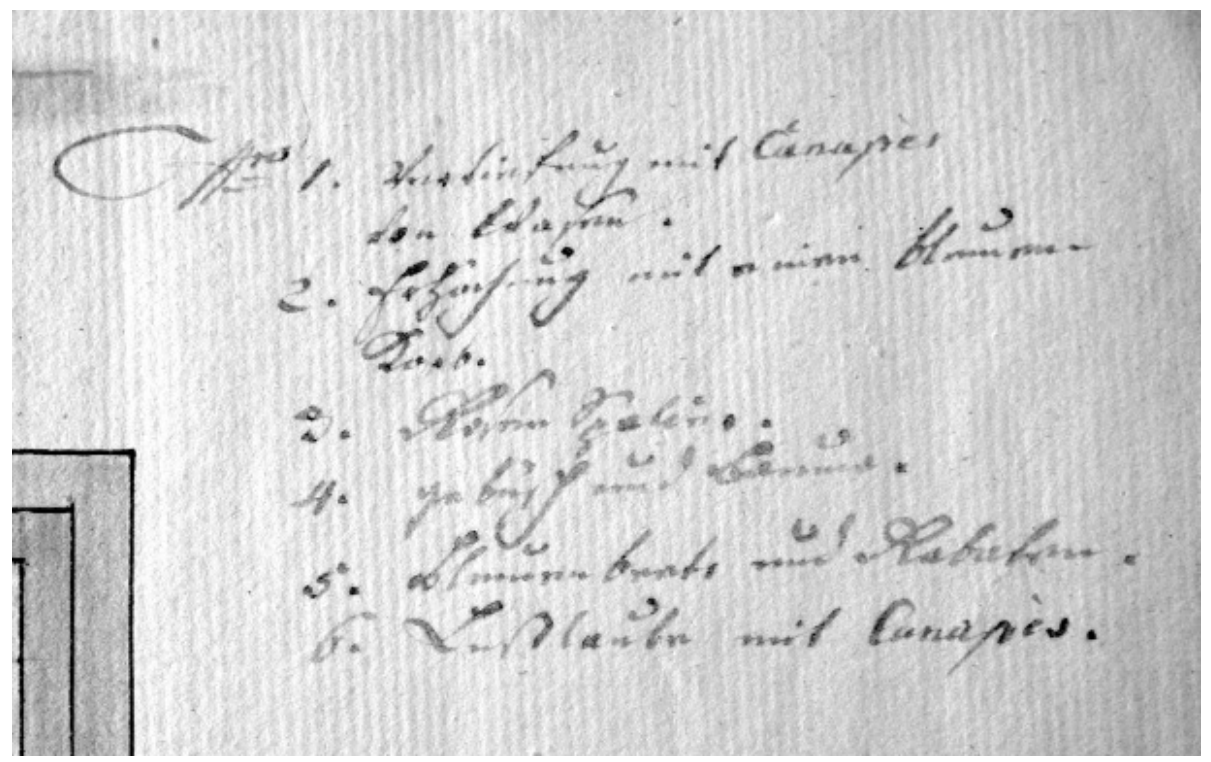

Slika 2: Načrt vrtnih zasnov, detajl vir: Arhiv Republike Slovenije

$\mathrm{Na}$ načrtu viden del objekta semenišča in sama velikost vrta kažeta na to, da je načrt za vrtni zasnovi nastal za prostor današnjega Pogačarjevega trga. Površina današnjega prostora trga, ki ga omejujejo stavba Kresije, škofijska palača, semenišče in struga Ljubljanice, je približno $60 \times 20 \mathrm{~m}$. Načrtovana vrtna površina pa bi zavzemala prostor, ki meri približno $59 \times 17 \mathrm{~m}^{3}$

Ob pregledu načrtov za ta del mesta iz 18. in 19. stoletja lahko vidimo, da je bila obravnavana površina nezazidana oziroma da so na njej stali le pomožni objekti ter da je bila najverjetneje ograjena. Zemljevid iz leta $1744,{ }^{4}$ na primer, prikazuje na tem predelu - med Špitalom, semeniščem, Ljubljanico in škofijsko palačo - ograjen prostor s pomožnim samostoječim objektom, ki bi lahko bil lesena tržna lopa. Načrti mesta iz prve polovice 19. stoletja ${ }^{5}$ prikazujejo situacijo na tem prostoru bolj nejasno. Večinoma lahko vidimo ograjen prostor, pomožne objekte ali celo prazno površino. Izjema sta

3 Urejena površina meri najmanj $31 \times 9$ klafter oziroma največ $34,5 \times 11,5 \mathrm{~m}$ (daljša os se zagrize v objekt semenišča). Najdaljša razdalja med škofijsko palačo in strugo Ljubljanice meri okoli $22 \mathrm{~m}$ (klaftra $=1,896 \mathrm{~m})$.

4 Janez Dizma Florijančič, detajl 3. lista obarvanega izvoda stenske karte Tabula chorographica Ducatus Carnioliae ..., 1744 (objavljeno v: Korošec, 1991, 53).

5 Arhiv Republike Slovenije (AS), AS 1068, 5/98 iz leta 1823, 5/99 iz leta 1827, 5/100 iz leta 1829, $5 / 102$ iz leta $1830,5 / 103$ in 5/104,5/105 in 5/106 iz leta $1853,5 / 125-126$ iz leta 1813 , iz leta 1827 , 5/128 iz leta 1828, 5/129 iz leta 1858; gl. tudi načrte, objavljene v Korošec (1991, 100-101, 106-107, 114-115); SI ZAL LJU 334, 001-002, a. e. 10, Ljubljanica in Gruberjev kanal, 1834 (izris) oziroma 1933 (dopolnjeno, kolorirano); SI ZAL LJU 337, Zemljevidi in karte, a. e. 3, 1827; Arhiv Republike Slovenije (AS), 176, Franciscejski kataster za Kranjsko, 1823-96. 
načrta, ki kažeta, da se je vsaj med letoma 1820 in 1834 na tem prostoru raztezal urejen vrt. Načrt iz leta $1820^{6}$ kaže na dvoje predeljen vrt, prav tako vidimo na načrtu iz leta $1834,{ }^{7}$ da je vrt za škofijsko palačo tedaj še vedno obstajal. Tudi situacijski načrt tega dela Ljubljane za potrebe ureditve tržnice, ki ga je pripravila deželna gradbena direkcija leta $1827,{ }^{8}$ kaže preprosto zeleno površino, razdeljeno na dva dela.

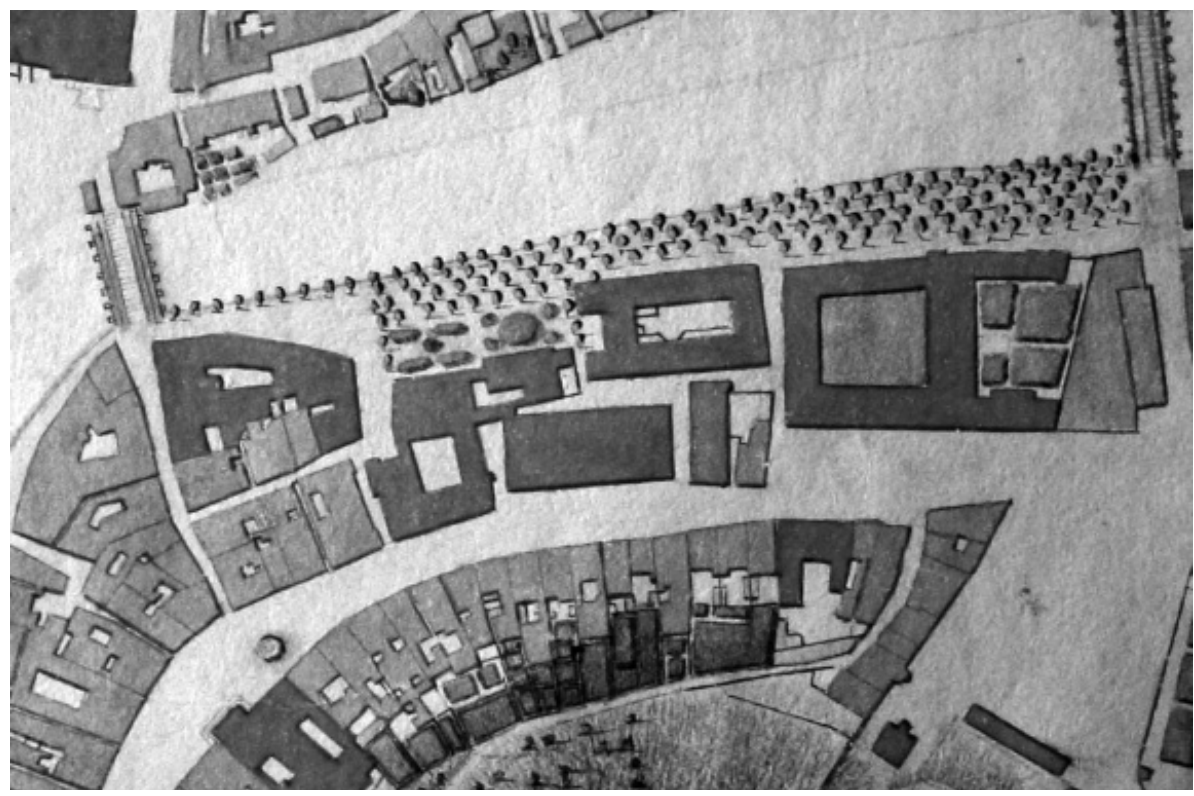

Slika 3: Načrt mesta Ljubljane, detajl, 1820 vir: Arhiv Republike Slovenije

Kdaj se je na današnjem Pogačarjevem trgu prvič pojavila vrtna zasnova, je težko reči. Prvi znani arhivski viri, ki posredno obravnavajo tudi ta prostor, so zapuščinski inventarji ljubljanskih škofov. V zapuščinskem inventarju iz leta 1597, ki popisuje imetje v škofijski palači po smrti škofa Janeza Tavčarja (škof med letoma 1580 in 1597), je med naštetimi prostori imenovana tudi soba nasproti vrtovom ali škofova soba. ${ }^{9}$ Glede na ta podatek predvidevamo, da je vrt v 16. stoletju na obravnavanem mestu že obstajal. Med prostori je $\mathrm{v}$ tem inventarju imenovana tudi velika soba proti vodi. ${ }^{10}$ Sobo proti vodi omenjajo tudi škofovski zapuščinski inventarji iz let $1630^{11}$ in $1641^{12}$

6 Ljubljana, Arhiv Republike Slovenije (AS), AS 1068, 5/97 iz leta 1820.

7 Gl. reprodukcijo v: Korošec $(1991,112)$; temu podoben je nedatiran načrt v Arhivu Republike Slovenije (Ljubljana, AS 1068, Zbirka načrtov, 5/164).

8 SI ZAL LJU 334, 001-002, a. e. 2, Petkovškovo nabrežje, 1827.

9 Nadškofijski arhiv Ljubljana (NŠaL), INV/Š, fasc. 1, šk. Inv. 2/b; gl. tudi Turk $(2004,22)$.

10 »Voda« bi se v tem primeru lahko poleg reke Ljubljanice nanašala tudi na vodnjak.

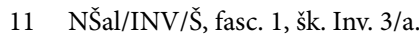

$12 \mathrm{NŠal} / \mathrm{INV} / \check{S}$, fasc. 1, šk. Inv. 4. 
ter približno petdeset let pozneje, ko so leta 1683 popisali zapuščino škofa Jožefa grofa Rabatte. V tem inventarju zasledimo sobo nasproti vode in mesnih stojnic, ne pa več sobe nasproti vrtovom. ${ }^{13}$ Vrt, ki je očitno ob koncu 16. stoletja res obstajal, je verjetno dal zasaditi Krištof pl. Ravbar (knezoškof med letoma 1488 oziroma 1493 in 1536). Ta je namreč po potresu leta 1511 temeljito prezidal škofijsko palačo (Steska, 1926, 28; Kokole, 2003, 184), vrt pa bi moral biti v tistem času sestavni del vsake rezidence humanističnega izobraženca. Toda $\mathrm{v}$ poznem 16. in zgodnjem 17. stoletju se je vrt zarastel in naposled izginil. Najpozneje v drugi polovici 17. stoletja so ga namreč mestni svétniki spremenili v tržni prostor. V starejši literaturi sicer lahko preberemo, da si je že škof Ernest Amadej grof Attems (knezoškof med 1742 in 1757) prizadeval pridobiti ta prostor med palačo in Ljubljanico nazaj, in sicer za povečanje palače in vrta, vendar mu magistrat tega ni dovolil (Steska, 1926, 30; Turk, 2004, 34). Škof Attems je temeljito prezidal svoji rezidenci v Gornjem Gradu in Goričanah, kjer je uredil tudi vrt, podobno pa je nameraval narediti še v Ljubljani (Weigl, 2000, 14, 69-71; Mavrič, 2009,172 ). Leta 1747 je celo sklenil pogodbo za vrtno zasnovo z avstrijskim krajinskim arhitektom Franzom Antonom Danreiterjem (Schnitzler-Sekyra, 2010, 461), a načrta nista realizirala. Attems pa v svoji nameri ni bil osamljen. O novi želji po posegu v prostor današnjega Pogačarjevega trga poročajo dokumenti iz leta 1775. Ohranjena je namreč pritožba mesta Ljubljane nad zahtevo, da se tržne lope okoli škofijske palače poruši. ${ }^{14} \mathrm{~V}$ pritožbi so mestni svétniki in sodnik podali svoje argumente proti porušitvi tržnih lop. Menili so, da je bil prostor že od nekdaj namenjen tržnim dejavnostim, da trgovci veliko prispevajo k letnemu dobičku mesta ter da Ljubljana in trgovci potrebujejo ta prostor, ki je v mestu edini dovolj širok, saj so sicer ulice tako ozke, da se še vozovi težko prebijajo skoznje. Prav tako so bili prepričani, da mesto potrebuje velik trg za izvajanje sejmov, saj premaknitev tržnih lop in sejmov iz mesta ne bi bila le velik strošek, ampak tudi velika izguba za trgovce. Predvsem pa jih je jezilo, da gre za prostor "... wo es noch keinem als S: fürstl: gnaden unsern dermachligen herrn herrn ordinario bisher eingefallen ist uns dawon zu Verdringen, Vermütlich um sich unter diesen Vorwand mehr Plaz zu verschaffen, und sodann den lähren orts ohne Entgelt für sich einzunemmen ${ }^{15}$ Poleg tega so meščani menili, da je nevarnost požara zaradi lesenih lop za cerkveno gospodo le izgovor, saj bi morali potemtakem podreti celo mesto. ${ }^{16}$ Iz pritožbe je torej mogoče razbrati željo nasprotne stranke, da bi prostor med škofijsko palačo in Ljubljanico spet postal škofova last oziroma da bi škof odrejal vsebino tega prostora. Škofom prav gotovo ni bilo všeč, da so imeli hrupen in (pre)

$13 \mathrm{NŠal} / \mathrm{INV} / \mathrm{S}$, fasc. 4 , šk. Inv. 8.

14 SI ZAL LJU 489, Mesto Ljubljana, splošna mestna registratura, Reg. I, fasc. 6, fol. 79-86.

15 SI ZAL LJU 489, Mesto Ljubljana, splošna mestna registratura, Reg. I, fasc. 6, fol. 81.

16 "... so hätten die Vorfahrer bischöfe zu Laybach wider die daselbstige Errichtung solhanner hölzenen Markthüten protestirt und nicht zugelassen, dass dieselbe so nahe an den bistumlichen gebäu aufgeführt worden wäre« (SI ZAL LJU 489, Mesto Ljubljana, splošna mestna registratura, Reg. I, fasc. 6 , fol. 82', 83). 
živahen tržni prostor v neposredni bližini rezidence. Nemara je bil poskus ponovne ureditve vrta ena izmed želja škofa Karla Janeza Herbersteina (knezoškof med 1772 in 1787), ki je okrog leta 1778 prezidal palačo (Prelovšek, 1984, 186). Da se domnevne Herbersteinove želje niso uresničile, pričajo dokumenti o obnovi tržnih lop iz leta 1786 in celo o gradnji novih iz leta $1789 .{ }^{17}$ Po letu 1787 je mesto začelo urejati vse mestne trge; glavni razlog za to je bilo rušenje mestnega zidu (Suhadolnik, 1997, 15). Leta 1790 je bilo spet napisano poročilo kot odziv na željo škofije po prestavitvi tržnih lop za škofijsko palačo. Med drugim je mestni svet odločil, da mesto ne more prepustiti velike proste površine zasebnemu lastniku, ampak morajo takšni trgi ostati $\mathrm{v}$ uporabi prebivalcev, za olepšanje ali povečanje okolice in za bolj zdravo bivanje $\mathrm{v}$ mestu, saj takšne površine omogočajo prosto kroženje zraka. ${ }^{18} \mathrm{Z}$ vso gotovostjo so zapisali, da »Von Seite des Magistrats ist man mehr, als sicher, das Erzbistum Laibach kein Recht auf den Platz der Markthutten habe $« .{ }^{19}$ Meščani so si želeli tudi prestavitve mesnic in klavnic, ki so stale ob Ljubljanici, bližje Špitala. To se jim je zdelo smiselno, vendar bi bilo v tem primeru treba najti zanje prostor ob vodi in blizu glavne ceste. ${ }^{20}$ Premestitev mesarskih lop je podpiral tudi deželni inženir Joseph Schemerl (predvsem iz higieničnih razlogov), glede tržnih lop pa je priporočal povečanje njihovega števila ter po potrebi premično in leseno obliko. ${ }^{21}$ Toda rešitev tega vprašanja so prestavili na bolj ugodne čase. ${ }^{22}$ Iz načrtov, ohranjenih v Zgodovinskem arhivu Ljubljana, izvemo, da je bila želja po boljši ureditvi tega prostora za tržno dejavnost, ki prevladuje še danes, aktualna še naslednjih petdeset let. Nerealiziran načrt Andreja Meninija iz leta 1795 namreč prikazuje že obstoječe tržne lope na bregu Ljubljanice in predvideva postavitev novih ob škofijski palači. ${ }^{23}$ Situacijski načrt iz leta $1831^{24}$ kaže, da je bila ideja o povečanju števila tržnih lop še vedno živa - na Pogačarjevem trgu naj bi stali dve vrsti lop (ki pa se ne bi dotikale škofijske palače kot po Meninijevem načrtu iz leta 1795), vendar situacijski načrt iz leta $1832^{25}$ prikazuje zgolj eno vrsto tržnih lop (na mestu starih), kar kaže, da do širjenja površine tržnih lop ni prišlo.

17 SI ZAL LJU 489, Mesto Ljubljana, splošna mestna registratura, Reg. I, fasc. 6, fol. 292-357.

18 »Der Magistrat kann es mit guter Einsicht nicht zugeben, das Plätze besonderes am Orten, wo der Raum moge, und die Verwendung zur Verschönerung, oder anderer nutzlichen Absicht bestimt werden kann, zur priwaten Verwendung uberlassen werden « (SI ZAL LJU 489, Mesto Ljubljana, splošna mestna registratura, Reg. I, fasc. 6, fol. 338).

19 SI ZAL LJU 489, Mesto Ljubljana, splošna mestna registratura, Reg. I, fasc. 6, fol. 338, 338'.

20 SI ZAL LJU 489, Mesto Ljubljana, splošna mestna registratura, Reg. I, fasc. 6, fol. 339.

21 SI ZAL LJU 489, Mesto Ljubljana, splošna mestna registratura, Reg. I, fasc. 6, fol. 341-342.

22 SI ZAL LJU 489, Mesto Ljubljana, splošna mestna registratura, Reg. I, fasc. 6, fol. 343-450'.

23 SI ZAL LJU 334, NAČRTI 18/1, 1795.

24 Gl. reprodukcijo v: Korošec $(1991,102)$ (Situacijski načrt mestnega trga za moko za škofijskim dvorcem v Ljubljani, 1831, avtor: Benedikt Müller). 


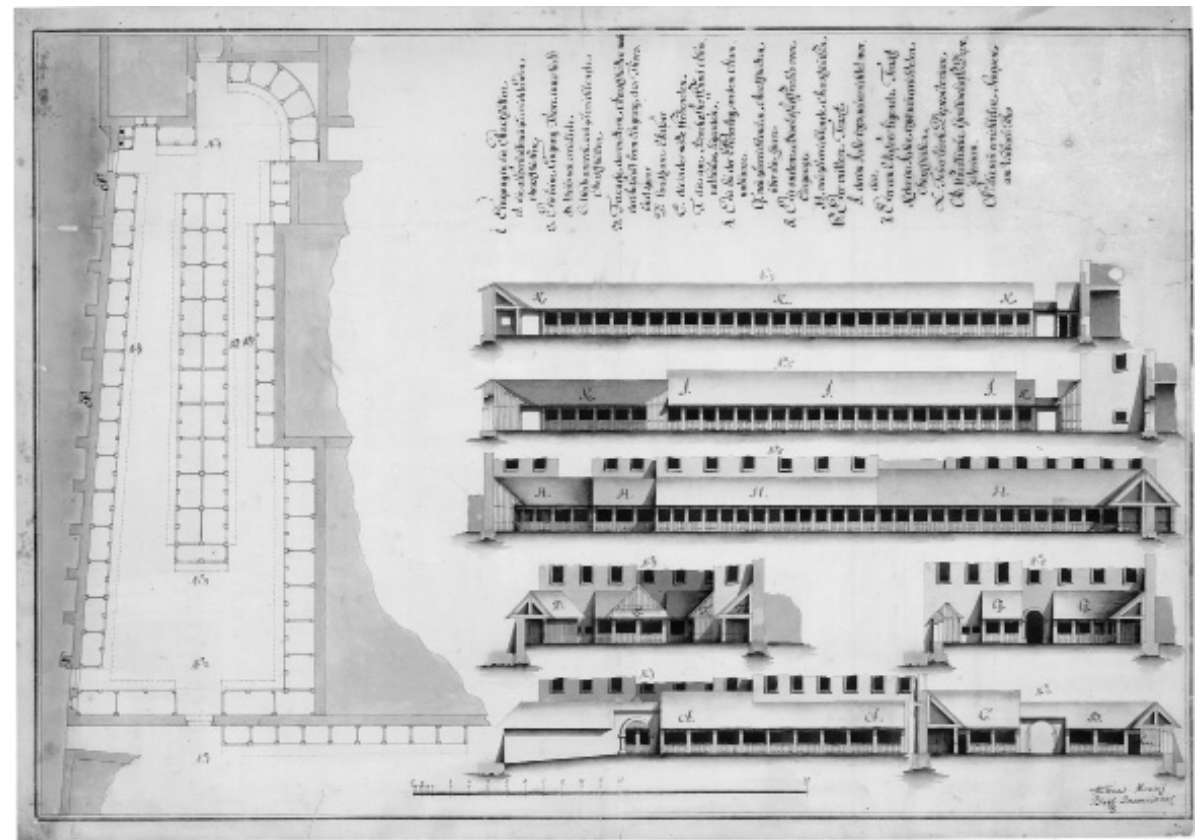

Slika 4: Andreas Menini, načrt za ureditev mestnih lop na današnjem Pogačarjevem trgu, 1795

vir: Zgodovinski arhiv Ljubljana

Naslednja omemba vrta $v$ inventarjih škofijske palače je šele iz časa francoskih Ilirskih provinc, ko je imela škofijska palača vlogo vladne palače. V inventarju, ki je nastal v Ljubljani decembra leta $1812,{ }^{26}$ sta namreč imenovana dva prostora: Chambre donnat sur le Jardin in Chambre a Càté de l'escalier du Jardin. ${ }^{27} \mathrm{O}$ ureditvi vrta $\mathrm{v}$ tem času lahko beremo v članku, ki ga je leta 1894 I. Vrhovec objavil v Ljubljanskem zvonu (Vrhovec, 1894, 14-18). ${ }^{28} \mathrm{~V}$ času francoske oblasti naj bi po njegovih navedbah ljubljanski trgovec Primic na svoje stroške splaniral prostor za škofijsko palačo oziroma Kramarski trg, kar je tudi Francoze spodbudilo k ureditvi tega prostora (Vrhovec, 1894, 15). Iz še ohranjenih virov pa izvemo, da so za ureditev oziroma vzpostavitev vrta zadolžili vrtnarja Franza Michaela Rieda, ki je v začetku leta 1812 začel saditi domače in tuje rastlinske vrste. Priskrbel je tako drevesa kot okrasne rastline, z izjemo belega gabra. Njegovo delo je potekalo pod nadzorstvom trgovca in mestnega svetnika Josipa Alborgettija. ${ }^{29}$ Vrtnar Ried se v svojem pismu z dne 17. septembra leta 1813 pritožuje, ker za svoj trud in delo (to je poleg zasaditve po zasnovi vključevalo tudi prenašanje

26 SI ZAL LJU 489, Mesto Ljubljana, splošna mestna registratura, Reg. I, fasc. 164, fol. 86،

27 SI ZAL LJU 489, Mesto Ljubljana, splošna mestna registratura, Reg. I, fasc. 164, fol. 78, 78،

28 Na žalost avtor ne navaja virov, najverjetneje pa je vse podatke pridobil iz: SI ZAL LJU 489, Mesto Ljubljana, splošna mestna registratura, Reg. I, fasc. 241, fol. 792-837.

29 SI ZAL LJU 489, Mesto Ljubljana, splošna mestna registratura, Reg. I, fasc. 241, fol. 793. 
štirih pomarančevcev $\mathrm{v}$ steklenjak za čas od oktobra do maja) ni dobil primernega plačila. ${ }^{30}$ Hkrati pa opozarja, da bi bilo treba nadomestiti neavtohtone grmovnice, akacijo in druga drevesa primerno zavarovati pred vetrom in snegom ter vrt ustrezno vzdrževati. ${ }^{31}$ Iz te prošnje je še mogoče razbrati, da je vrtnar v vrt poleg svojega časa in truda vložil tudi nekaj lastnega denarja. ${ }^{32}$ Iz ohranjenih dokumentov ni jasno, ali je bil denar Riedu povrnjen, je pa vrtnar ponovno prosil za plačilo oziroma za njegovo zvišanje v letu 1820 , vendar tokrat za delo na šolskem drevoredu. ${ }^{33}$

Kmalu po umiku Francozov iz Ljubljane, že leta 1814, se je pojavilo vprašanje, kaj bo z vrtom za škofijsko palačo, ki so ga takrat poimenovali »ein Garten fur das Publikum «. ${ }^{34}$ Vprašanje se je pojavilo tudi kot odziv na posege $\mathrm{v}$ ta prostor, saj je dal magistrat porušiti zid, ki je vrt obdajal. To pa je sprožilo neodobravanje ilirskega guvernerja barona Lattermanna, ki je želel, da se ohrani stanje, kakršno je bilo v času francoske oblasti. ${ }^{35}$ Vrt je postal kar naenkrat zelo zanimiv tako za mesto kot za državo in škofijo. ${ }^{36}$ Spor se je v letu 1815 rešil v prid mesta, ki naj bi vrt ohranilo za javnost tudi v prihodnje. ${ }^{37} \mathrm{~V}$ tem letu je mesto že načrtovalo povezavo vrta s šolskim drevoredom ter njegovo preureditev $\mathrm{v}$ prostor sprostitve za dijake liceja in gojence semenišča oziroma v poletnem času za otroke, ki še potrebujejo varstvo. ${ }^{38}$ Proti koncu leta 1815 je ljubljanski okrožni urad poročal o velikem obisku vrta, predvsem v večernih urah, kar je povzročilo dodaten strošek razsvetljave ${ }^{39}$ Vendar to ni bil edini problem na tem prostoru. Zaradi nesreč pri Ljubljanici je bilo treba v letu 1816 narediti živico pred brežino in zaradi poškodb ograditi drevesa, poškodovane pa so bile tudi trajnice in vrtna oprema, zaradi česar je gradbena inšpekcija želela uvesti (policijski) nadzor nad vrtom. ${ }^{40} \mathrm{O}$ škodi v vrtu (na drevesih, klopeh, živici) poročajo tudi leta 1817 , glavni krivci pa naj bi bili otroci in mladina (šolarji). Za ureditev oziroma vzdrževalna dela na šolskem drevoredu so (vsaj) leta 1819 najeli vrtnarja Rieda. Ta 3. junija leta 1820 poroča o svojem opravljenem delu (predvsem obrezovanju dreves), o podirajočem

30 SI ZAL LJU 489, Mesto Ljubljana, splošna mestna registratura, Reg. I, fasc. 241, fol. 793, 793'.

31 SI ZAL LJU 489, Mesto Ljubljana, splošna mestna registratura, Reg. I, fasc. 241, fol. 793'.

32 "Seine Löbliche Mairie von Laibach geruhe dernach als Eigenthumer dieses Gartens, diesen meiner Vortrag zubeherzigen, und meiner auf bescheidenheit verwendete Zeit, Mühe, und Auslagen, großguttig zuentschädigen.« (SI ZAL LJU 489, Mesto Ljubljana, splošna mestna registratura, Reg. I, fasc. 241, fol. 793')

33 SI ZAL LJU 489, Mesto Ljubljana, splošna mestna registratura, Reg. I, fasc. 241, fol. 827.

34 SI ZAL LJU 489, Mesto Ljubljana, splošna mestna registratura, Reg. I, fasc. 241, fol. 801.

35 SI ZAL LJU 489, Mesto Ljubljana, splošna mestna registratura, Reg. I, fasc. 241, fol. 792.

36 SI ZAL LJU 489, Mesto Ljubljana, splošna mestna registratura, Reg. I, fasc. 241, fol. 803-809.

37 SI ZAL LJU 489, Mesto Ljubljana, splošna mestna registratura, Reg. I, fasc. 241, fol. 806-808, 809, $803 '$.

38 SI ZAL LJU 489, Mesto Ljubljana, splošna mestna registratura, Reg. I, fasc. 241, fol. 809-811.

39 SI ZAL LJU 489, Mesto Ljubljana, splošna mestna registratura, Reg. I, fasc. 241, fol. 812, gl. tudi ostale dokumente do 815 .

40 SI ZAL LJU 489, Mesto Ljubljana, splošna mestna registratura, Reg. I, fasc. 241, fol. 816. 
se zadnjem zidu ob drevoredu, o poškodovanem zaščitnem špalirju na nabrežju in o prepotrebnem posipanju poti ob semenišču. ${ }^{41}$ Za vzdrževanje vrta za škofijsko palačo pa Ried ni bil zadolžen. Zdi se, da so vrt ohranjali z minimalnimi vložki oziroma pustili, da se je ohranila zgolj zelena površina z nekaj drevesi in grmovnicami.

Vrt za škofijsko palačo je torej obstajal v 16. stoletju - verjetno ga je dal urediti knezoškof Krištof grof Ravbar. Ker se je konec 16. in v 17. stoletju zaraščal, ga je mesto spremenilo v tržnico. Škofje so si sicer v drugi polovici 18. stoletja prizadevali prostor dobiti nazaj oziroma si tam spet urediti vrt za svoje potrebe, vendar jim to ni uspelo. Ideja o vrtu je spet postala aktualna $\mathrm{v}$ času francoske oblasti, ko so škofijski dvorec spremenili v vladno palačo. Vrt je začel nastajati vsaj leta 1812, ko je vrtnar Ried začel z zasajanjem te površine, opuščen pa je bil že dobrih dvajset let po nastanku. Kdo in kdaj je torej naročil načrt dveh vrtnih zasnov, hranjen v Arhivu Republike Slovenije? Je bil to knezoškof Attems ali knezoškof Herberstein (oba sta si vsak na svoj način skušala pridobiti tržni prostor za škofijsko palačo) ali pa je bil to kateri od guvernerjev Ilirskih provinc, ki so imeli svoj sedež v škofijski palači? Delni odgovor nam ponuja literatura, v kateri lahko preberemo, da je leta 1812 guverner izdal nalog, naj se tržni prostor na današnjem Pogačarjevem trgu spremeni v javni vrt (Valenčič, 1966, 150; Suhadolnik, 1997, 11). Natančnejšega datuma oziroma imena guvernerja pa avtorja ne navajata. Glede na to, da je v februarju leta 1812 guvernerja Betranda na tej funkciji zamenjal Junot, ${ }^{42}$ bi za določitev naročnika potrebovali natančen datum t. i. naloga. Iz originalnega dokumenta, ki sta ga citirala Vrhovnik in Suhadolnik, izvemo, da je bil nalog izdan 4. julija 1812. Torej bi lahko sklepali, da je bil tudi naročnik izdelave vrta guverner Junot. ${ }^{43} \mathrm{~V}$ francoščini pisani dokument je pravzaprav naslovljen na »Monsieu

41 SI ZAL LJU 489, Mesto Ljubljana, splošna mestna registratura, Reg. I, fasc. 241, fol. 827. Ried je bil v letu 1819 in 1820 zadolžen za vzdrževanje drevoreda. Potegoval se je za nadaljevanje tega dela in boljše plačilo (fol. 831). Glede zadnjega je ohranjenega kar nekaj pisanja (SI ZAL LJU 489, Mesto Ljubljana, splošna mestna registratura, Reg. I, fasc. 241, fol. 820-829, 833 ...), v katerem se pojavi tudi vprašanje: »ob der erwähnte Kunstgartner (Ried) wirklich einen betrag mit $96 \mathrm{f} \mathrm{m}$. m. Verdinnt habe« (SI ZAL LJU 489, Mesto Ljubljana, splošna mestna registratura, Reg. I, fasc. 241, fol. 821). Riedu so 6. septembra 1820 obnovili pogodbo za leto 1821 ter opredelili njegovo delo: vzdrževanje dreves, poti, celo klopi (za katere lahko skrbi z lastnimi zimmerleuten), živic iz gloga. Dovoljeno mu je bilo celo, da naredi novo zasnovo, si vzame nekatere podmladke živice, pobira plodove oreha in zbira listje. Poleg tega je bilo zaželjeno, da je brežina reke zasajena le z varovalno živico, da je treba ostala drevesa (razen oreha) odstraniti in zmanjšati obseg trnatega grmičevja v živici. Zaželjeno pa je bilo tudi, da se vhod v alejo pri mesnicah uredi kot pri drugih drevoredih - kot prepoznaven vhod, križišče (SI ZAL LJU 489, Mesto Ljubljana, splošna mestna registratura, Reg. I, fasc. 241, fol. 834). Najverjetneje so pogodbo Riedu vsaj še enkrat podaljšali, saj je iz leta 1822 ohranjeno njegovo pismo, v katerem priporoča skrajšanje previsokih orehov ob šolskih poslopjih zaradi jemanja svetlobe prvemu nadstropju (SI ZAL LJU 489, Mesto Ljubljana, splošna mestna registratura, Reg. I, fasc. 241, fol. 837).

42 Prvi guverner, maršal Marmont, je bil imenovan 8. oktobra 1809. Za njim je 9. aprila 1811 vodenje prevzel Henri-Gratien Bertrand, ki je to funkcijo opravljal do 21. februarja 1812, ko je bil imenovan Jean-Andoche Junot (Reisp in Zelinkova, 1964, 124; Šumrada in Klasinc Škofljanec, 2005, 700, 701). 
le maire / Sou exellence le Gouvermen Général ...« « ${ }^{44}$ podpisal pa ga je generalni policijski komisar za Kranjsko. Dopis omenja aktualna, možna in nujna popravila na javni promenadi ${ }^{45}$ in ne omenja javnega vrta. Tako ostaja vprašanje naročnika odprto, saj iz dokumenta izvemo le, da je v letu 1812 obstajala javna promenada.

Slogovne značilnosti zasnov na obravnavanem načrtu so značilne za pozno 18 . stoletje oziroma za prvo polovico 19. stoletja. Zasnovi imata jasne poznobaročne poteze, kot so vezeninasti vzorci, pasovi oziroma robovi posameznih kopartimentov, posodovke, drevesca z oblikovanimi krošnjami, boulgreen ipd. Po drugi strani pa lahko vidimo že nekatere krajinske poteze: mehke valujoče linije, ki razdelijo posamezne ploskve. Poseben element so cvetlične gredice, ki prav tako spadajo v prehodno obdobje med obema pristopoma vrtnega oblikovanja. Močno razrahljane oblike gredic kažejo na rokoko, cvetlični motivi pa na bidermajer. ${ }^{46}$

Prav cvetlične grede oziroma blumen Korb so značilen element bidermajerskih vrtov, ki se je začel pojavljati po letu 1790. Cvetlične motive, ki so začeli izpodrivati (oziroma tudi nadgrajevati) klasične francoske parterje, je uvajala takratna sodobna literatura. Pomemben pisec vrtnoarhitekturnih del v tem času je bil krajinski arhitekt Humphry Repton (1752-1818). ${ }^{47}$ Repton spada v čas novega vrtnega okusa, ki ga je sprožilo angleško krajinsko oblikovanje..$^{48}$ Vendar se vrtna umetnost ni spremenila kar čez noč; po letu 1750 je nastalo še veliko vrtov s parterji ali z drugimi formalnimi elementi. Toda ti vrtovi zaradi Walpolovega programskega teksta in družbenih sprememb niso bili več zanimivi, tako da jih tudi niso preučevali ali spremljali (Rogger, 2007, 53). Repton v novem vrtnem okusu ni videl zgolj krajinskega oblikovanja, ki bi posnemalo naravo, saj je to po njegovem mnenju učinkovalo nenaravno in celo utrujajoče. Menil je, da je treba v vrtu združevati različne elemente, ki jih je mogoče v vsaki situaciji nekoliko drugače oblikovati. Sam je poleg raznovrstnih motivov cvetličnih vrtov priporočal uporabo raznih (lesenih) konstrukcij, ki so bile obrasle dodaten okras cvetličnim gredam, svetoval pa je tudi uporabo parternih elementov pred glavnim objektom (das Herrenhaus) oziroma $\mathrm{v}$ delu parka, imenovanem Pleasureground (Wimmer, 1989, 237-238; Rogger, 2007, 53-54). Dober pričevalec Reptonovih idej je njegova zasnova sekvence vrtov v t. i. Woburn Abbey iz leta 1805 (Rogger, 2007, 54). Vrtni zasnovi na obravnavanem ljubljanskem načrtu kažeta novo

44 SI ZAL LJU 489, Mesto Ljubljana, splošna mestna registratura, Reg. I, fasc. 161, fol. 496.

45 SI ZAL LJU 489, Mesto Ljubljana, splošna mestna registratura, Reg. I, fasc. 161, fol. 496.

46 Iskreno se zahvaljujeva zakoncema dr. Beatrix in dr. Gezi Hajos, ki sta pomagala pri slogovni analizi načrta.

47 Prvo delo z vrtnoarhitekturno tematiko je izšlo leta 1794 (Wimmer, 1989, 227).

48 Angleško krajinsko oblikovanje je postalo edino pravo vrtno oblikovanje in je, kot zapiše Sir Horace Walpole (1717-1797), doseglo točko popolnosti. Walpole je izdal tudi tekst z naslovom The History of the Modern Taste in Gardening, prvič v svojih Anacdotes of Painting in England (1771) kot sklepno poglavje v četrtem zvezku (Rogger, 2007, 51, 52). 
pojmovanje okrasnih vrtov in bivalnega prostora sploh. Stanovanje, katerega sestavni del je bil tudi vrt, je v 19. stoletju postajalo kozmos vsakega meščana (Althöfer, 1956, 44-46). ${ }^{49}$ Od poznega 18. stoletja dalje so vrtovi postajali tudi osrednje družabno zbirališče za meščane. Bili so nekakšni »cvetlični templji«, ki so lastniku in njegovim prijateljem s svojo barvitostjo in raznoliko zasnovo nudili pravo pašo za oči. Raznovrstnost cvetlic je postala prava umetnost oziroma pomemben element bivanja. Vrtnica, orlica, perunika, cesarski tulipan, tulipan, zlatenec, ognjeni grm, kapucinček, avrikelj in vijolica so se znašli v pasovih (Rabatten), cvetličnih krogih, amfiteatrih in loncih (Pindor, 1993, 250).
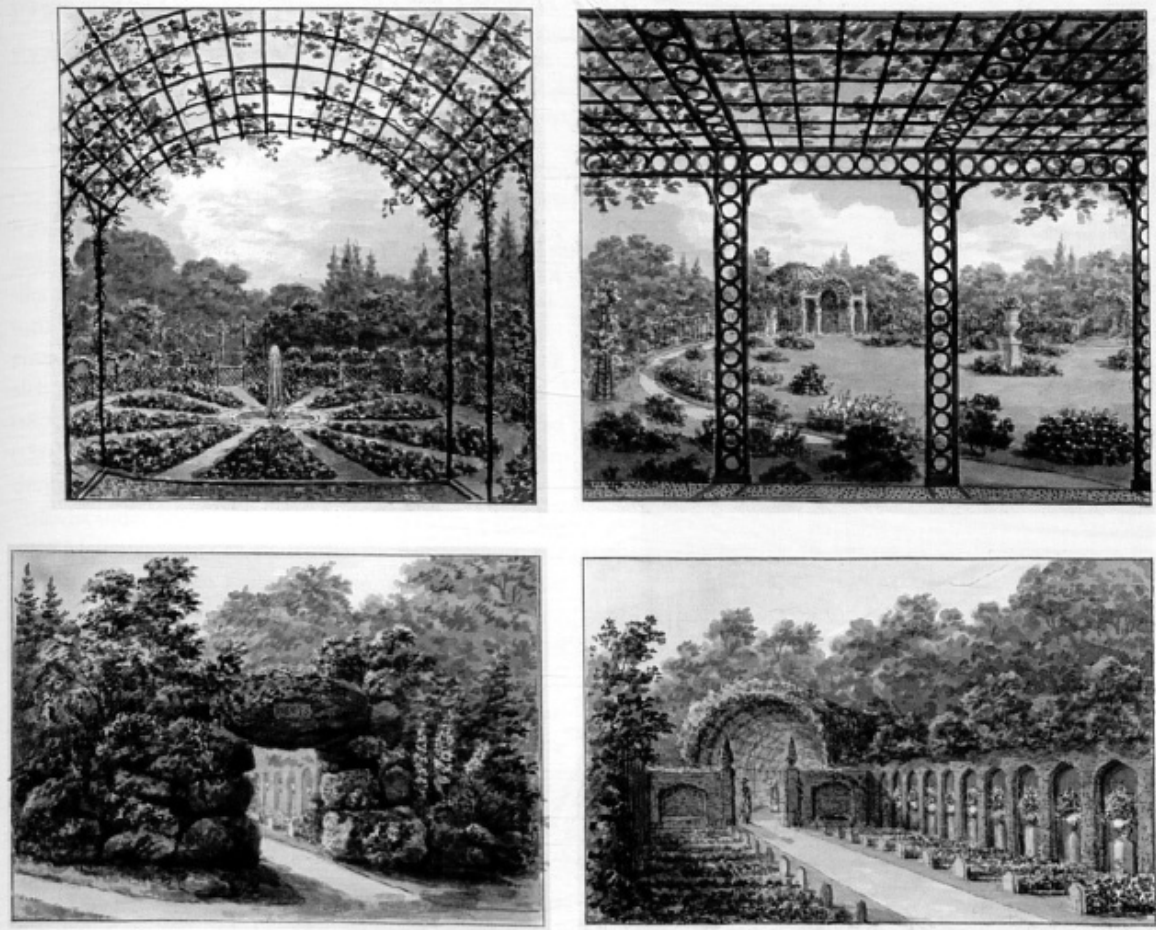

Slika 5: Predlogi Humphryja Reptona za vrtno ureditev v Ashridgeu iz leta 1813 vir: Schäfer, 1995, 245

$\mathrm{V}$ tem duhu je deloval tudi knez Pückler-Muskau, eden najpomembnejših oblikovalcev vrtov v nemškem prostoru, ki je širil nov krajinski slog. Pleasureground ${ }^{50}$ je razumel kot podaljšek stanovanja, ki mora okras dvorca prenesti navzven, zato ga je

49 V 19. stoletju je imela skoraj vsaka hiša vrt, ki je bil na začetku sicer zelenjavni vrt ali sadovnjak, pozneje pa so se $\mathrm{v}$ teh vrtovih prepletale uporabne in estetske funkcije.

50 Pleasureground je površina nepravilnih oblik, posebej bogato okrašena s cvetnicami, okrasnimi grmovnicami, manjšimi arhitekturami in premično vrtno opremo. Navadno obdaja okrasni vrt oziroma Ziergarten in ga ločuje od ostalega dela parka. Za angleške dežele je bilo značilno, da je bil okrasni vrt neposredno ob dvorcu, navadno samo ob eni stranici objekta. 
umeščal okoli celotnega dvorca oziroma objekta (Schäfer, 1995, 190). Med njegovimi deli so vrtovi v Babelsbergu, Branitzu in Muskauu. Pleasureground je od ostalega parka ponavadi ločil z dvignjeno teraso ali jarkom »aha . $^{51} \mathrm{~V}$ Babelsbergu (vrt, zasnovan leta 1844) je bila neposredna okolica dvorca dvignjena v teraso (die Voltaireterrasse), ki jo je krasilo stopnišče, obogateno z živalskimi plastikami, balustradami z vazami in gmotami kamenja, v niši terase pa je stal neogotski marmorni vodnjak, ki ga je spremljala klop, podprta s figurama pritlikavcev. Zlato teraso (die Goldterrasse) severno od gradu Babelsberg so sestavljali cvetlični parterji, cvetlična fontana ter vaza iz rastlinja in zlate žice. Uporaba pozlačenih in bronastih stojal za rože je povečala barvit učinek konstrukcij, cvetlic, zelenja in belega marmorja. Tej zlati terasi je sledila porcelanasta (die Porzellanterrasse) z lovorjem, novozelandskim lanom, plastikami živali, balustrado, vodnjakom in kitajskimi klopmi iz keramike ali porcelana (Schäfer, 1995, 190-192). Okrasni vrt na terasi v Branitzu (oblikovan po letu 1846) so krasile vaze, balustrada, festoni, svetilke, cvetlice, posodovke ipd., v Muskauu (po letu 1825) pa toploljubne rastline, cvetlični vrt (Rosary), ${ }^{52}$ cvetlične gredice različnih oblik in sestave (sončnice, vrtnice, trajnice, čebulnice), najraje v raznovrstnih močnih barvah (Schäfer, 1995, 192-196). Zelo nazorni so primeri teh vrtov, ki jih je knez tudi objavil v knjigi Andeutung über Landschaftsgartnerei, izdani v Stuttgartu leta 1834 (PücklerMuskau, 1834). Slikovni material iz te knjige nam daje dobro predstavo o tem, kakšna bi lahko bila npr. cvetlična košara v ljubljanskem škofijskem vrtu.

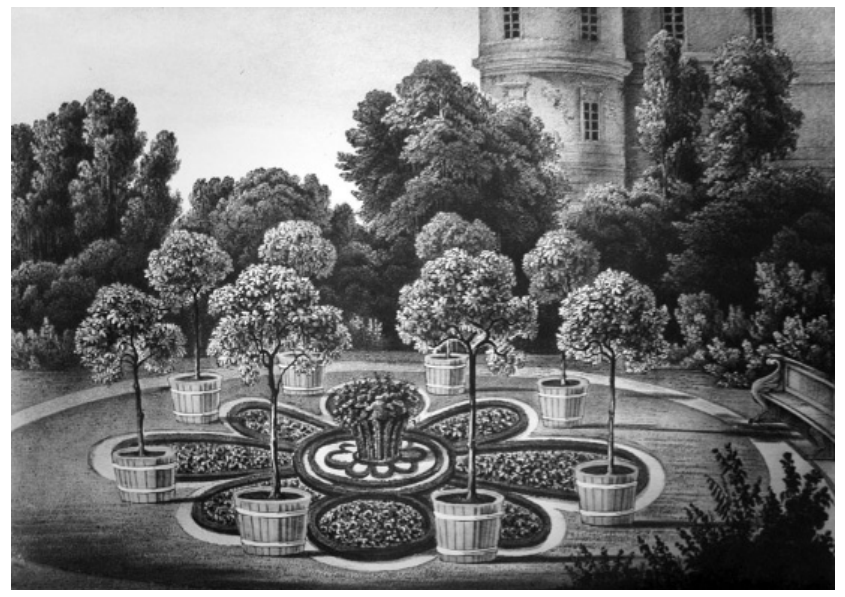

Slika 6: Ena izmed ilustracij v knjigi Hermanna von Pückler-Muskau vir: Pückler-Muskau, 1834

51 Jarek »aha« oziroma »ha, ha!« je globok jarek, ki ima dovolj strme brežine, da iz njega ni mogoče priplezati. Stranice so utrjene in na eni strani omejene z zidcem, ki je tako nizek, da ne ovira pogleda na pokrajino. Skoraj neopazen pri obiskovalcu sproži takšno »ha, ha!« reakcijo (gl. Kluckert, 2000, 228, 229).

52 Schäfer, 1995, 192. Nekakšna rozeta iz cvetlic, razporejenih v osem listov, obrobljenih s pušpanom in z Blumenkorb s pozlačenimi konci na sredini. Okoli pa so rasla še drevesca granatnih jabolk (Schäfer, 1995, 193). 
Tudi nam bližnji Dunaj je v prvih desetletjih 19. stoletja doživel novo gradbeno modo, t. i. Baulust (Althöfer, 1956, 34), ki se je najlepše izrazila v predmestjih (npr. Hietzing). Nastajati so začela predmestja, polna vrtov. Ti so večinoma še imeli tipično zasnovo hišnih zelenjavnih vrtov (pravilne oblike gred), znano iz srednjega veka, vendar so bili veliko bolj bogati in pestri v barvah, rastlinskih vrstah, okrasju in opremi, zato jih že lahko imamo za bidermajerske. Prva precej svojevrstna zasnova je bil vrt Rosenbaum, ki je začel nastajati po letu 1816 kot prava pomanjšava angleškega parka (Althöfer, 1956, 34-36). Zasnovo vrta sestavljajo posamezne grede nepravilnih oblik in vijugaste poti ter množica drugih elementov kot: cvetlične grede, grede okrasnega grmičevja, drevesca, brv, vrtni šotor, cvetno gledališče, visok steber, topoli, gugalnica, kip Flore, uokvirjen s cvetlicami, grotta pod mostom, fontana, gotski stolp itd. Vrt je obsegal $3.597 \mathrm{~m}^{2}$, na njem pa je raslo okoli 40.000 cvetlic (Althöfer, 1956, 5-11). Teh bidermajerskih vrtov sicer ne moremo označiti zgolj kot pomanjšane angleške vrtove, saj sledijo razvojni fazi hišnih vrtov, poskušajo pa ustvariti ravnovesje med naravo in umetnostjo - jasno želijo pokazati, da gre za delo človeških rok, na majhno površino pa vnašajo množico vrtnih, arhitekturnih in umetniških elementov (Pindor, 1993, 250).

Prav taki sta tudi zasnovi na obravnavanem ljubljanskem načrtu. Sicer ju še zaznamujejo poznobaročni vrtni elementi, ki pa so že dopolnjeni z rokokojsko razrahljanimi linijami in bidermajersko pisanimi cvetličnimi motivi. Torej naročnik načrta ni mogel biti knezoškof Herberstein, ampak moramo nastanek načrta pomakniti v začetek 19. stoletja, natančneje malo pred letom 1812, ko je vrt že začel nastajati. Pri izvedbi vrta so najverjetneje sledili načrtu. Na načrtu Ljubljane iz leta 1820 namreč vidimo, da je bil vrt razdeljen na dva dela, prav tako, kot predvidevata obe vrtni zasnovi. Da pa je bil vrt precej ambiciozno uresničen, dokazuje prisotnost najetega vrtnarja.

Vrt očitno ni bil projektiran za zasebno guvernerjevo uporabo, ampak kot javna površina. Na načrtu je namreč vidno, da naj bi se ograja vrta z dvema vhodoma odpirala proti Ljubljanici in Kresiji, ena večja odprtina, ki deluje kot glavni vhod in odpira neposreden pogled na fontano, pa bi vodila v škofijsko palačo. Vendar ob pregledu ohranjenih načrtov palače takšnega povezovanja ni mogoče jasno videti. Načrti prezidave palače iz leta 1830 in $1881^{53}$ ne predvidevajo vratnih odprtin na tem mestu, prav tako pomožni objekti nimajo vrat na severno stran. Le na načrtu namembnosti posameznih prostorov palače, ki je nastal oziroma bil dopolnjen $\mathrm{v}$ času francoske oblasti (med letoma 1809 in 1814), ${ }^{54}$ lahko ob severni stranici vidimo urejeno stopnišče, vendar ni razvidno, da bi vodilo na vrt. Vsi zbrani podatki in

53 AS 1068, 6/51, 6/52.

54 NŠaL, mapa načrtov, tloris prvega nadstropja nadškofijske palače. 
sama slogovna analiza kažejo kot najbolj verjetnega naročnika omenjenih vrtnih zasnov visokega predstavnika francoske oblasti v Ljubljani. Temu v prid pa priča tudi velika angažiranost oblasti in posledično javnosti za ozelenjevanje mesta in razvoj botanike v tistem času (Melik, 1986, 424). Ta odnos se ne kaže le v nastanku mnogih drevoredov oziroma promenad, pač pa tudi v ustanovitvi Botaničnega vrta v Ljubljani leta 1810 (Lazar, 1954, 105), ${ }^{55}$ za katerega je bila podlaga rastlinska zbirka licejskega vrta. ${ }^{56}$

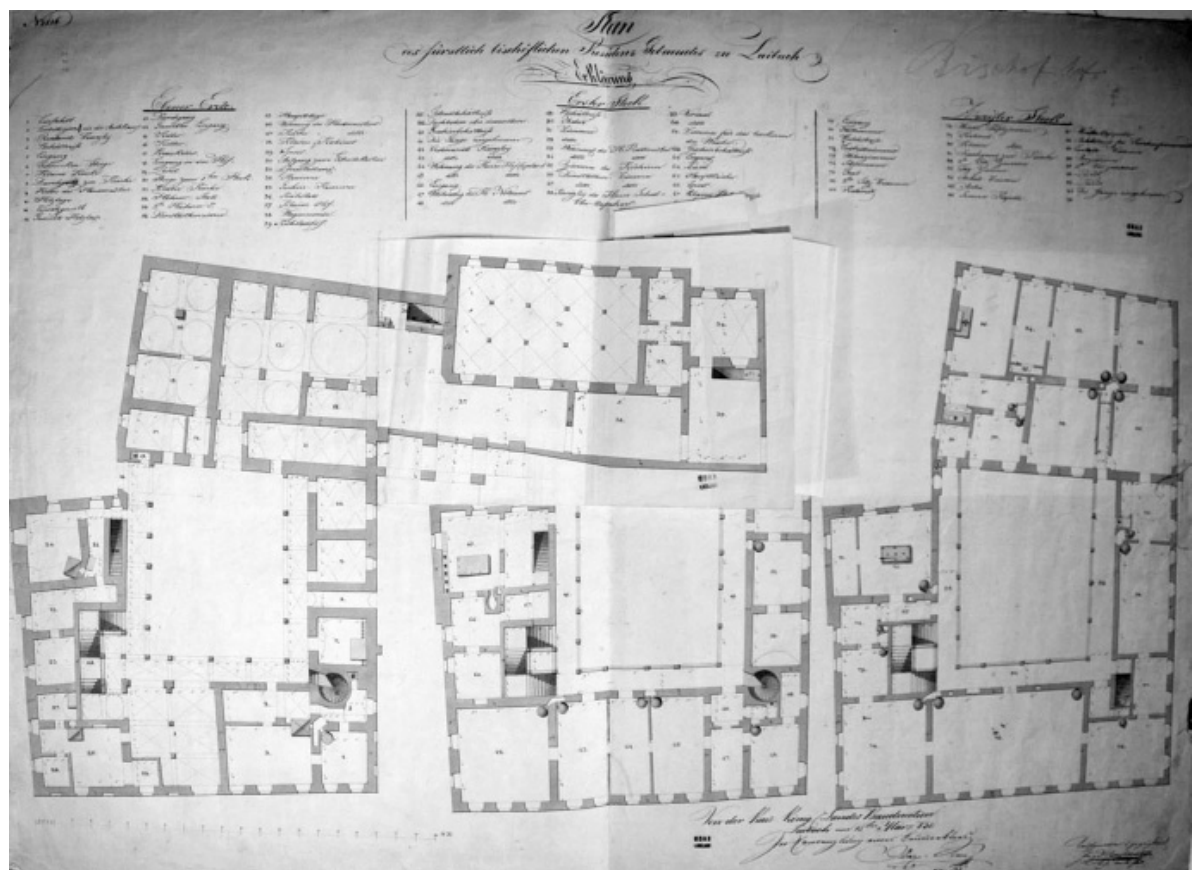

Slika 7: Načrt škofijske palače iz leta 1830 vir: Arhiv Republike Slovenije

55 V Ljubljani so že pred ustanovitvijo Botaničnega vrta obstajali manjši vrtovi z izbranimi rastlinskimi vrstami. Tak primer je bil vrt kmetijske družbe na Poljanah, ki ga je imel Baltazar Hacquet za potrebe svojih predavanj. Drug znan primer, t. i. Zoisova aleja, plod dela obeh bratov Zois, pa se je raztezal na sedanji Zoisovi cesti in ga lahko imenujemo tudi prvi botanični vrt v Ljubljani (Lazar, 1954, 105; Voss, 2008, 179).

56 Na obsežnem dvorišču liceja je namreč na začetku 19. stoletja obstajal vrt z mnogimi rastlinskimi vrstami kranjske flore, ki jih je gojil Franc Hladnik. Nedolgo po francoski zasedbi je maršal Marmont predal površino ob Ižanski cesti Hladniku, da jo spremeni v »vrt domovinske flore« (Lazar, 1954, 105-106; Bavcon, 2000, 7; Voss, 2008, 179; gl. tudi Baras, 1984, 215). Tako je leta 1810 začel nastajati botanični vrt, ki je bil del École centrale, ustanovljene istega leta (prva uredba francoskih oblasti o organizaciji šolstva Ilirskih provinc je bil odlok maršala Marmonta z dne 4. julija 1810; Šumrada, 1999, 517). 


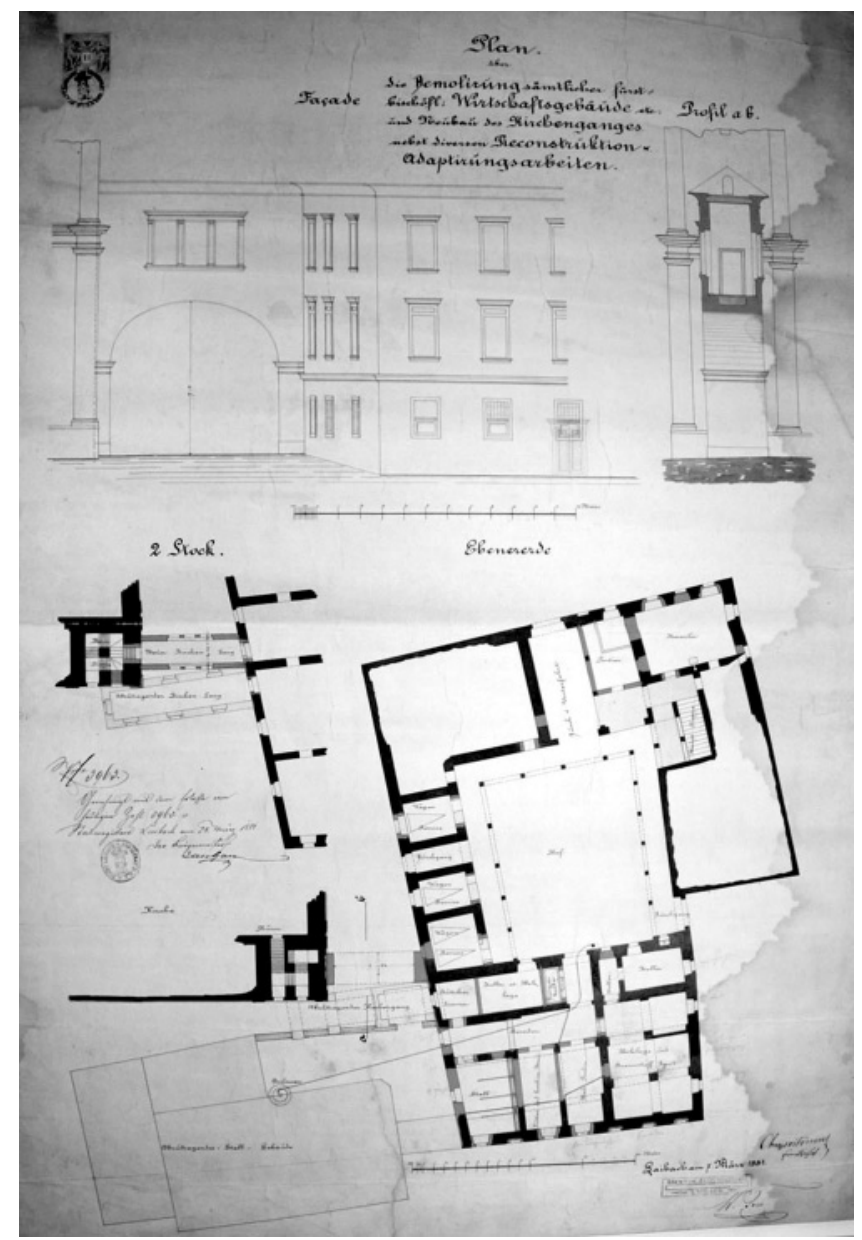

Slika 8: Načrt škofijske palače iz leta 1881

vir: Arhiv Republike Slovenije

Raznoliki vrtni elementi, bogate cvetlične grede in vzorci ter arhitekturna oprema na načrtu vrta škofijske palače kažejo na bidermajerski način oblikovanja. Letnica 1812 pa umešča škofijski vrt med zgodnejše primere bidermajerskih vrtov v srednjeevropskem prostoru. Obravnavani vrt se tako izkaže kot nadvse zanimiv in kvaliteten pojav v zgodovini vrtnega oblikovanja pri nas. Prav zato je na mestu tehten premislek, ali ne bi kazalo teh dveh bidermajerskih zasnov realizirati oziroma s papirja prenesti v realni svet. Obstoj takšnega arhivskega vira je gotovo treba upoštevati, saj raziskovanje zgodovine umetnosti mnogokrat ustavi pomanjkanje podatkov. Pogačarjev trg sicer ne dopušča realizacije takšne zelene površine, bi se pa kot možna lokacija lahko izkazal dvorec Goričane, kjer je vrtno površino treba še urediti. 


\section{Viri}

Ljubljana, Arhiv Republike Slovenije (AS), AS 1068, 6/50.

Ljubljana, Arhiv Republike Slovenije (AS), AS 1068, 6/51.

Ljubljana, Arhiv Republike Slovenije (AS), AS 1068, 6/52.

Ljubljana, Arhiv Republike Slovenije (AS), AS 1068, 5/96.

Ljubljana, Arhiv Republike Slovenije (AS), AS 1068, 5/97, 1820.

Ljubljana, Arhiv Republike Slovenije (AS), AS 1068, 5/98, 1823.

Ljubljana, Arhiv Republike Slovenije (AS), AS 1068, 5/99, 1827.

Ljubljana, Arhiv Republike Slovenije (AS), AS 1068, 5/100, 1829.

Ljubljana, Arhiv Republike Slovenije (AS), AS 1068, 5/102, 1830.

Ljubljana, Arhiv Republike Slovenije (AS), AS 1068, 5/103.

Ljubljana, Arhiv Republike Slovenije (AS), AS 1068, 5/104.

Ljubljana, Arhiv Republike Slovenije (AS), AS 1068, 5/105, 1853.

Ljubljana, Arhiv Republike Slovenije (AS), AS 1068, 5/106, 1853.

Ljubljana, Arhiv Republike Slovenije (AS), AS 1068, 5/125-126, 1813.

Ljubljana, Arhiv Republike Slovenije (AS), AS 1068, 5/127, 1827.

Ljubljana, Arhiv Republike Slovenije (AS), AS 1068, 5/128, 1828.

Ljubljana, Arhiv Republike Slovenije (AS), AS 1068, 5/129, 1858.

Ljubljana, Arhiv Republike Slovenije (AS), AS 1068, 5/164.

Ljubljana, Arhiv Republike Slovenije (AS), AS 176, Franciscejski kataster za Kranjsko, 1823-96.

Ljubljana, Nadškofijski arhiv Ljubljana (NŠaL), mapa načrtov, tloris prvega nadstropja nadškofijske palače.

Ljubljana, Nadškofijski arhiv Ljubljana (NŠaL), NŠal/INV/Š, fasc. 1, šk. inv. 2/b, 3/2, 4.

Ljubljana, Nadškofijski arhiv Ljubljana (NŠaL), NŠal/INV/Š, fasc. 4, šk. inv. 8.

SI ZAL LJU 489, Mesto Ljubljana, splošna mestna registratura, Reg. I, fasc. 6, fol. 79$86,292-357$.

SI ZAL LJU 489, Mesto Ljubljana, splošna mestna registratura, Reg. I, fasc. 161, fol. 496.

SI ZAL LJU 489, Mesto Ljubljana, splošna mestna registratura, Reg. I, fasc. 164, fol. $78,78,86^{\circ}$.

SI ZAL LJU 489, Mesto Ljubljana, splošna mestna registratura, Reg. I, fasc. 241, fol. 792-837. 
SI ZAL LJU 334, NAČRTI 18/1 (Andreas Menini), 1795.

SI ZAL LJU 334, NAČRTI 18/1, Tržnice za moko na Pogačarjevem trgu, 1832.

SI ZAL LJU 334, 001-002, a. e. 2, Petkovškovo nabrežje (F. v. Muil, Deželna gradbena direkcija), 1827.

SI ZAL LJU 334, 001-002, a. e. 10, Ljubljanica in Gruberjev kanal (Deželna gradbena direkcija v Ljubljani), 1834 (izris) oziroma 1933 (dopolnjeno, kolorirano).

SI ZAL LJU 337, Zemljevidi in karte, a. e. 3, Ljubljana, glavno mesto Ilirskega kraljestva (F. Deschmann), 1827.

\section{Literatura}

Althöfer, H., Der Biedermeiergarten, München, 1956 (doktorska disertacija, Univerza v Münchnu, tipkopis).

Bajec in drugi, Slovar slovenskega knjižnega jezika. Knjiga 1: A-H, Ljubljana, 1970.

Baras, F., Maršal Marmont: Memoari, Split, 1984.

Bavcon, J., Botanični vrt v Ljubljani. »Vrt domovinske flore«: Botanical garden in Ljubljana. »Native Flora Garden«, Ljubljana, 2000.

Dolinar, F. M., Ljubljanski škofje, v: Upodobitve ljubljanskih škofov (Ljubljana, Narodna galerija, 19. 6.-30. 9. 2007, ur. Ana Lavrič), Ljubljana, 2007, 11-89.

Kokole, S., Totius antiquitatis egregius admirator: Christophorus Raubar zwischen Kampanien und Krain, v: Bayern und Slowenien in der Früh- und Spätgotik: Beziehungen, Anregungen, Parallelen (ur. Höfler, J., Traeger, J.), Regensburg, 2003, 175-197.

Korošec, B., Ljubljana skozi stoletja. Mesto na načrtih, projektih in $v$ stvarnosti, Ljubljana, 1991.

Kluckert, E., European garden design. From classical antiquity to the present day, Cologne, 2000.

Lazar, J., Botanični vrt v Ljubljani. Njegov nastanek in razvoj, Kronika, II/2 (1954), 105-109.

Mavrič, D., Vrt ob nadškofijskem dvorcu v Goričanah - njegova podoba in pomen skozi čas, v: Predmet kot reprezentanca: okus, ugled, moč - Objects as manifestations of taste, prestige and power (ur. Maja Lozar Štamcar), Ljubljana, 2009, 165-204.

Melik, V., Ilirske province v slovenski zgodovini, Zgodovinski časopis, XL, Ljubljana, 1986, 423-429.

Pindor, P., Ein Bidermeiergarten in der Großstadt (VII. Bezirk, Seidengasse 31), v: Historische Gärten in Österreich, Wien, Köln, Wiemar, 1993, 250-252. 
Prelovšek, D., Ljubljanska arhitektura 18. stoletja, v: Zgodovina Ljubljane: prispevki za monografijo: gradivo s Posvetovanja o zgodovini Ljubljane, 16. in 17. novembra 1983 v Ljubljani (ur. Gestrin, F.), Ljubljana, 1984.

Pückler-Muskau, H., Andeutungen über Landschaftsgärtnerei, Stuttgart, 1834.

Reisp, B. in Zelinkova, D., Napoleonove Ilirske province 1809-1814 (Ljubljana, Narodni muzej v Ljubljani), Ljubljana, 1964.

Rogger, A., Die Red Books des Landschaftskünstlers Humphry Repton, Worms, 2007.

Schäfer, A., Zur Ausstattung von Landschaftsgärten im 19. Jahrhundert mit Kleinarchitekturen, mobilen Gartenausstattungen und Pflanzungen unter besonderer Berücksichtigung von Park Branitz, v: Der Parkschöpfer PücklerMuskau (ur. Rippl, H.), Weimar, 1995.

Schnitzler-Sekyra, A. A., Franz Anton Danreiter (1695-1760), Barockberichte: Informationsblätter des Salzburger Barockmuseums zur bildenden Kunst des 17. und 18. Jahrhunderts, 53/54 (2010), 451-484.

Smolik, M., Kako so zidali semenišče v Ljubljani, Kronika: časopis za slovensko krajevno zgodovino, VII (1959), 90-96.

Steska, V., Ljubljanski škofijski dvorec, Zbornik za umetnostno zgodovino, VI (1926), 25-41.

Suhadolnik, J., Živilski trg in Plečnikove tržnice z okolico v zgodovini. Arhitekturni in zgodovinski oris predela med Ljubljanico, Ciril-Metodovim trgom, Stritarjevo in Kopitarjevo ulico ter arhivsko gradivo Zgodovinskega arhiva Ljubljana (Ljubljana, avla Zgodovinskega arhiva Ljubljana), Ljubljana, 1997.

Šumrada, J., Načrti francoskih oblasti v Iliriji o ustanovitvi ljubljanske univerze, v: Gestrinov zbornik (ur. Mihelič, D.), Ljubljana, 1999, 517-534.

Šumrada, J. in Klasinc Škofljanec, A., Glavni intendant Ilirskih provinc. 1809-1813, $\mathrm{v}$ : Napoléon et son administration en Adriatique orientale et dans les Alpes de l'Est 1806-1814 (ur. Kolanović, J., Šumrada, J.), Zagreb, 2005, 699-702.

Turk, M., Nadškofijska palača v Ljubljani, Ljubljana, 2004 (diplomsko delo, Univerza v Ljubljani, tipkopis).

Valenčič, V., Oblikovanje Ljubljane v prvi polovici XIX. stoletja, v: Kronika: časopis za slovensko krajevno zgodovino, XIV/3 (1966), 141-152.

Voss, W., Versuch einer Geschichte der Botanik in Krain (1754 bis 1883). Poskus zgodovine botanike na Kranjskem (1754 do 1883), Celje, 2008.

Vrhovec, I., Iz domače zgodovine. Prva izprehajališča in prvi javni nasadi v Ljubljani, Ljubljanski zvon, 1894, 12-18 (samo o vrtu: 14-18), 76-83.

Weigl, I., Matija Persky. Arhitektura in družba sredi 18. stoletja, Ljubljana, 2000. (magistrsko delo, Univerza v Ljubljani, tipkopis). 
Ines Unetič, Metoda Kemperl

\section{The Bishop's Palace Garden in Ljubljana}

Keywords: garden design, Bishop's Palace, Ljubljana, urbanism, Illyrian Provinces, Biedermeier

There was not always a market square behind the Bishop's Palace in Ljubljana. In the sixteenth century, this space was occupied by a garden that was reshaped into a space for market stalls as early as the seventeenth century. The prince-bishops Count Ernst Amadeus Attems and Count Karl Johann von Herberstein tried to appropriate the space as diocesan property, but without success. The empty space (today Pogačar Square), located between the Bishop's Palace, the Seminary, the Kresija Palace, and the Ljubljanica River, was turned into a public garden by the Illyrian governor only around 1812. However, due to maintenance costs and regime changes, the garden was not kept in its original form for long. As evident in some plans from the first half of the nineteenth century, the garden eventually became two green areas with no garden design features. A garden plan kept in the Archives of Slovenia shows diverse garden elements, opulent flowerbeds and patterns, and architectural garden elements, which indicate that the garden was designed in Biedermeier style. This plan, dating back to 1812, places the Bishop's Palace garden among the earliest examples of Biedermeier gardens in Central Europe. The garden therefore represents a very interesting and high-quality example in the history of garden design in Slovenia. 